Duncan noted when he reviewed this article: "The unknown aspects, the element of surprise, this is what makes observing nature so compelling."

1. Bancroft, F. [Jean]. 1977. Sora in a tree. Blue Jay 35: 101.

2. Belcher, M. 1980. Birds of Regina. Revised ed. Special Publication No. 12, SNHS, Regina.151pp.

3. Berger, R.P., and D. Chranowski. 1993. Peregrine Falcon recovery project: Manitoba perspective. Pp. 333341 In Proc. Third Prairie Cons. \& Endangered Species Workshop. Nat. Hist. Occas. Paper No. 19. Prov. Mus. Alberta. Edmonton.

4. Callin, E.M. 1980. Birds of the Qu'Appelle, 1857-1979. Special Publication No. 13. SNHS, Regina. 168 pp.

5. Gardner, K.A. 1981. Birds of Oak Hammock Marsh Wildlife Mgt. Area. Man. Wild. Bn. Winnipeg. 172pp.
6. Green, J. C., and R.B. Janssen. 1975. Minnesota birds, where, when and how many. U. Minn. Press, Minneapolis. 217pp.

7. Houston, C.S., and M.G. Street. 1959. The birds of the Saskatchewan River, Carlton to Cumberland. Special Publication No. 2, SNHS, Regina. 205pp.

8. Knapton, R.W. 1979. Birds of the Gainsborough-Lyleton region. Special Publication No. 10, SNHS, Regina. 72pp.

9. Nero, R.W. 1984. Redwings. Smithsonian Institute Press, Washington, D.C. 160pp.

10. Nero, R.W. 1989. Heaven's own bird: Peregrine Falcons nest in Winnipeg. Manitoba Naturalists Society Bull. 14 (8): 15-16.

11. Randall, T.E. 1962. Unusual nest site of Sora. Blue Jay 20: 116.

12. Thompson, E.E. 1891. The birds of Manitoba. Second Ed. Premium Ventures Ltd. 1975, Winnipeg. 643pp.

\title{
OF RAVENS, GULLS AND A PELICAN
}

\author{
VICTOR C. FRIESEN, P.O. Box 65, Rosthern, SK SOK 3R0
}

A few years ago, I and two companions were diverted from our fishing at Damour Lake (north of Blaine Lake) by the aerial display of six Common Ravens. The flying gymnastics lasted more than an hour. A steep hill abutted one shore, and the birds were continually wheeling about, riding in and out of the rising air currents caused by strong winds. Dives, tumbles, and wing-overs were part of their performance.

Taverner describes ravens' behaviour as "sometimes very playful in the air." 2
Indeed, at times these birds appeared to be taking turns in soaring up and then swooping down; occasionally, two birds might engage in a similar movement jointly. What was most interesting to watch were the embellishments often added: a raven's apparent out-of-control tumble, with wings flapping about, then an easy recovery - or a smoothly executed flipping over onto its back, with wings fully extended, followed by another flip to right itself. These moves were often combined with a downward plunge, all accomplished just above the 
crest of the hill, where the updrafts were greatest.

This past summer I have again been entertained by ravens, four of them this time, in my home town of Rosthern (a decade ago their mere presence in town, especially in summer, would have been noteworthy). They were also engaged in gymnastics, only now galeforce winds were blowing against the Saskatchewan Wheat Pool elevator at the end of the block on which I live. The ravens were doing barrel rolls - those aeronautical manoeuvres consisting of a continuous, complete roll over - about the roof of this 130 -foot-high structure.

Then on 13 June 2000, I had occasion to watch the aerial antics of two other species of birds at Greenwater Lake. At dusk, some Ring-billed Gulls stood along the shoreline, preening themselves. Now and then, a gull would lift off and sail in slow-wheeling arcs above me, before rejoining the others on the sand. There was an onshore breeze and, with trees behind me, probably some rising air currents to sail upon. Meanwhile, an American White Pelican, which I had seen earlier in the nearby marina, flew low over the lake and landed several hundred yards away in the water.

I continued watching the gulls and had tilted my head back to observe two of them sailing 20 feet above me, making a 50-foot-wide circle. All of a sudden, the pelican was there too, a part of the "circle game," and following one of the gulls ("following-the-leader," if you like).

When the gull dipped lower or swung higher, so did the pelican, always remaining 5 to 10 feet behind. They made one full circle before the gull flew off tangentially, only to loop back into its former circular course. The pelican replicated the manoeuver, but came out of it at a slightly higher plane. Thereupon it swooped down and narrowly passed over the gull (in effect, "buzzing" it).

While the ravens had no apparent purpose to their actions (other than playing), the pelican may have been trying to get the gull to disgorge food. Or was the larger bird, in part, possibly taking advantage of an opportunity to do what, according to Pough, the species seemingly "enjoy[s]" - "circling in small flocks"? ${ }^{1}$

The incident ended with the pelican continuing on and away, in a straight line, back to the marina, and the gulls dropping down to be once more among their fellows at the waterline.

1. Pough, R.H. 1951. Audubon Water Bird Guide. Doubleday, Garden City, NJ.

2. Taverner, P.A. 1928. Birds of Western Canada. National Museum of Canada, Ottawa.

"On one occasion, I saw a magpie on the ground and running and jumping about in a highly erratic manner. My first thought was that the bird was having an epileptic fit. Then, when I viewed the magpie in a telescope, I could see it was actually chasing a mouse or vole, which was frantically trying to escape by darting around in circles. The prey was eventually caught, held in the feet and killed by several hefty blows from the bill." T.R. Birkhead The Magpies. p.104 